\title{
Some Philosophical Approaches of Investigations of Indian Theology*
}

\author{
Ruzana Pskhu \\ Faculty of Humanities and Social Sciences \\ Department of History of Philosophy \\ Peoples' Friendship University of Russia (RUDN University) \\ 6 Miklukho-Maklaya Street \\ Moscow, Russian Federation 117198 \\ E-mail: r.pskhu@mail.ru
}

\begin{abstract}
The main task of this article is to analyze some philosophical approaches proposed by the contemporary scholars of religious hermeneutics and history of Indian Philosophy and Religions. The author tries to ponder and correlate the weak and strong points of each approach. The three approaches, which were elaborated on the base of Religious Hermeneutics and the investigation of Indian religious-philosophical thought, are represented in the works Gerhard Oberhammer (Austria), Francis X. Clooney (USA) and John B. Carman (USA). The article sums up the philosophical outcomes of the theoretical considerations of each scholar.
\end{abstract}

Keywords-comparative theology; interreligious hermeneutics; phenomenology of religion; clooney; carman; vishishta-advaita; ramanuja; oberhammer

Generally speaking, one could perhaps therefore say that new religious traditions develop from two fonts:

from a continuum of religious experience that lies within a contamination of the religious tradition and existential thinking; in a religious terminology: mysticism in communication with other religious traditions,

through their study, adoption and integration, as well as through rejection and differentiation.

They do not seem arise from mere philosophical intellectual efforts.

Gerhard Oberhammer [1]

\section{INTRODUCTION}

Today we live in a situation of the close co-existence of different religions and cultures. From the ancient times the religious pluralism and worldviews have been always in 'plural' form. But only at the end of the XX century and nowdaways we see that this religious pluralism discovers its own existence. We have lost our intimacy and privacy of our

*The publication has been prepared with the support of the "Russian Science Foundation”, project № 16-18-10427. religious life and have to live taking into account the claims of other religious traditions, which have the same ones. That fact changes the modus of thinking of the contemporary world: people have to take account the religious aspirations (or its absence) of each others. The problem is how to coordinate the external explanation of the alien religion and the inner expirience of the own religion in the manner which will allow them to co-existate in the world. To resolve this problem means to find a key to the puzzle why people chose to become Muslim or Hindu or someone else, rejecting their native religious tradition.

In such a situation the things, which seem to be very abstract and remote could help us to look at the problem with the unusual point of view. As an example of it the investigation and comparative correlation of various 'theologies' can become a great support to understand some specific issues of religious worldview. But there are some dangers in the direct use of the word 'theology'. As Francis $X$. Clooney says, "we need to be serious about the word "theology" in "comparative theology", in accord with features distinctive to a theological perspective. My strating point is not in comparative religion but in the insistence that this is an intellectual discipline grounded in faith, a true version of "faith seeking understanding" [2]. Let's consider in details the basic principles of such an approach.

\section{COMPARATIVE TheOlogy as TheOlogy: Francis X CLOONEY'S APPROACH}

The first principle which is underlines by Francis $\mathrm{X}$. Clooney is that the comparative theology of his type is not only the theoretical elaboration of some theological ideas of various religious constructions, but the constructive engagement with the possibilities of such a religious diversity [3]. In this sense his investigation of classical texts of pre-modern times should be considered as "a contribution to our understanding of the 21 st century religious diversity" [4].

The second principle is that the comparative theology must be deeply rooted in a particular religious tradition. In other words the comparative theologian should belong to a particular religious community of a definite religious tradition. Because a theologian who deals with comparative 
work does it first of all for his own living religious community. As a consequence he should understand the responsibility which he takes in face of his community for translating and explanation of the fundamental principles of the alien religious tradition.

The third principle is concerning with truth of the own religious tradition and the foreign one, even if some questions are very hard to be answered. And it means that a theologian is aware his responsibility before those people, whose religious tradition he is investigating, and at the same time he has a willingness to respect other traditions. Comparative theology "is not about the uniqueness of Christ nor about whether Hindus are saved or not. It is different kind of theologizing practice because of a particularly that has its own dynamic that is different of religions and related fields" [5]. If we take an analogy that comparative theology is a type of a dialogue, then we can agree with Francis X. Clooney that an interior dialogue can give a deeper spiritual meaning potentially, than a dialogue with representatives of a certain religious tradition.

Clooney says about two main obligations of a comparative theologian. One of them is to the professional academic community and the other one is to the community, whose religion he studies. "At every stage of our theological reflection, we need to keep a respectful sense of obligation to truth on both sides of this conversation, fostering respectful interaction in my comparative work" [6]. And there are two consequences of such a comparative theological method: firstly, it helps to strip away some 'protective defenses' of a scholar against the really transforming encounter with the other religion and culture. In this sense a comparative theologian is not talking about God, he prepares in a sense the encounter with God. And secondly, if we take into consideration the fact of influence of things someone studies or thinks about, then there occurs the possibility of 'multiple religious belonging'.

But Clooney's suggestion that a theology occurs "only after a particular comparative encounter has taken place, in the shape of a comparison that has been executed fairly and meticulously" [7] aroused some critical arguments of the Indologists and the Religious studies specialists. The comparative theology, which is understood as "the dialectical and dialogical activity of closely reading and rereading texts", creates 'a third space' and transforms into the comparative dynamic activity which evidently differs from the two separate spaces of the texts under investigation.

Clooney's demand for a comparative theologian to be rooted in his own religious tradition arouses some doubts, because it's not clear enough who is addressed by the terms "we", when Clooney is talking about "our religious tradition" or "we" in opposition to the others. And the suggestion that a lot of people will not feel themselves included it the pronounce "we" has its own foundation. Taking faith as a criterion and precondition for a comparative philosophy is rather questionable, because it means that someone, who doesn't belong to that tradition, is denied entrance. As a consequence of that the question is aroused: "would it not then rightfully be called theology otherwise?... Are scholars who do not belong to a tradition since there are many religious studies specialists today who write highly sensitive and insightful works on particular details of one or more religious tradition located elsewhere in the world - not equally equipped to produce what Clooney's comparative theology is aiming for?" [8] In other words is it possible at all to become altered in the process and "still remain a loyal to one's own tradition?". The aspect of truth is also shakable. And the example, mentioned by Clooney himself in the book "Theology after Vedanta. An Experiment in Comparative Theology" can form a certain dilemma can for a comparative theologian 1 .

The two features of Clooney's comparative theology ("its empirical method and its resistance to generalization about particular religion" [10] help to describe it as a nonhegemonic form of interreligious theological investigation. The romantic and subjective character of such an approach, expressed in Dilthey's Verstehen, is used in the various human sciences in contrast of the approach of objectifying and explicating used in the natural sciences.

Anyway Clooney's approach is based on the assumption that there is a possibility to make positive religious use of the study of another religious tradition and that is called as the comparative theology.

The balance between those who are adherent Cloneys' approach and those who are suspicious about it can be found in the interreligious hermeneutics which refers "to the theologically reflective engagement with the scripture(s) of another tradition, which takes place consciously from within one's own religious perspective" [11].

That can help us to avoid some abovementioned weak points of the comparative philosophy as a type of a theological practice.

\section{PHENOMENOLOGICAL APPROACH TO INDIAN THEOLOGY IN CARMAN'S VIEW}

The same principal demand to a scholar (to be rooted in a concrete religious tradition) is proposed by John B. Carman, who studied the doctrine of God of great Indian philosopher Ramanuja (XI-XII) as a Western Protestant Christian. But though he tried to understand a Hindu thinker as sympathetically as it is possible for one, who is outside the Hindu religion, generally he followed the principles of the phenomenology of religion, the main task of which is defined by prof. W. Brede Kristensen as a "the requirement negatively expressed: self-denial, letting the believer himself speak without our praise or blame into what he tells us; positively expressed, having an attitude of sympathetic and loving understanding toward the alien faith, which "sympathy" alone can lead toward comprehension and proper evaluation" [12].

\footnotetext{
"Which of the declarations is true?
}

1) The historical event of the Passion of Christ is the most fitting, and ultimately the only, source of the salvation for the world (Aquinas. Summa Theologica).

2) Knowledge of Brahman in all that is required for salvation (Advaitavedanta)" [9]. 
The negative demand of the phenomenology of religion means that a scholar refrains from any judgment while he is in the process of understanding another religious tradition, it is so called phenomenological epoché. The positive demand means that a scholar attempts to "relive in one's own experience that which is 'alien' or 'strange' or 'imaginative re-experiencing of a situation strange to us", based on his own entire religious background [13]. But trying to explain another religion in the terms and feelings of his own one, a scholar should avoid the situation of experience of the other religion as 'a power of life'. The last would mean for him going beyond the restrictions of his scientific research and becoming an adherent the religion under investigation.

The other principle, which includes both requirements, is that a scholar shouldn't follow a simple method. It means that a scholar will be involved totally in the process of understanding of the other religion, but constantly restrains himself in the emotional level. It means that the questions about truth and values are not the objects of a phenomenology of religion. Its object is "the understanding of the pattern and practice in the life of the believers of some other religion" [14]. But such a definition arouses some doubts: putting aside the question about truth transforms a religion into a kind of activity, which is chosen by people because they were born in this or that religious tradition or because it correlates to their personal taste. In other words there is a hidden dilemma of every religion: the most people take their religion as only a social or worldly practice, not taking it seriously, because in reality they don't devote themselves to realization of the main task of their religion. But there are some people (a few) who takes his/her religion absolutely seriously, being "the highest type of devotee, who worships God only for his sake and not for his/her own benefit" [15]. The last type is the only real object of the phenomenology of religion, which concerns about the religious pattern exemplified in such a devotee.

The fact is that such a phenomenological study of Indian theology imposes some limitations on a scholar, which can be overstepped only by his entering into realm of historical facts. The last one can help him to understand the situation, based mostly on some historical, cultural and linguistic realia, not based only on his own religious and human background.

\section{PRINCIPLES OF RELIGIOUS HERMENEUTICS IN OBERHAMMER's STUDY OF INDIAN PHILOSOPHY}

The religious experience in the comparative perspective is the subject of the investigations of the Austrian philosopher and Indologist Gerhard Oberhammer, who creates on the base on the deep study of the Indian Philosophy a system of special terms and notions, which laid foundation for his religious hermeneutics. The most important terms of Oberhammer's terminological 'inventions' are (1) the term of the "encounter" (Begegnung), which is understood "as a universally essential dimension of religious experience, explains the event of experiencing transcendence by the subject" [16] and (2) "mythization" (Mythisierung), which is interpreted as a process in which and by which Transcendence is embodied in a certain form and 'face', becoming attainable for 'an encounter' with the subject.

Oberhammer clarifies his approach by himself in the following words: "hermeneutics is an attempt to interpret the phenomenon of religion, not, however, in the sense of the theological understanding of what religion is, but in the sense of religion as a human phenomenon, unrestricted by dogmatic positions. Why does man have religion, in what does the essence of religion lie?" [17] The structure of the human subjectivity has in itself the key for understanding of the notion of Transcendity in Oberhammer's religious hermeneutics. It is the openness of a subject to the other. This openness of self-presence being (Beisichsein) to another subject forms the foundation the transcendental structure of the consciousness. Here we can notice thatOberhammer's approach aims at the phenomenological study of the human phenomenon of religiosity. But in comparison with two previous approaches Oberhammer gives the adequate place to a religious tradition in face of Transcendence. The question of truth and values becomes senseless, because there is no ground for comparison of different religious traditions except the only one - Transcendence. Then the main concern of such an approach is 'how the encounter with Transcendence arouses and how the subject's inner world becomes the place where God occurs?'. One of the most interesting and important works of Oberhammer [18] deals with this concern.

The term of Oberhammer's Religious Hermeneutics such as the "reaching-out" (Ausgriffe), the "encounter" (Begegnung), the "mythization" (Mythisierung), "Selfpresence" (Beisichsein), the" beyond-of-being" (Jenseits des Seienden), the "one towards whom one reaches out" (Woraufhin) because of their theological neutrality are beyond any particular theology, creating in this meaning a pure philosophical approach to a theology.

\section{CONCLUSION}

The strongest point of the comparative theology approach proposed by Clooney is that he neither presumes nor attempts to construct any kind of "God's eye view" or any kind of "view from nowhere" [19]. The concrete character of the theological position of the adherent of such an approach allows him not to save the vision of a person, who lives in a certain religious tradition and can estimate the other religious tradition from the point of his own religious interests and demands. In that sense it is a project of a practical knowledge, which intends to re-thinks and re-read one religious tradition from the point of view of the other in the new context. And as a such this project has more the educational potency, than the scientific one. Though the last one can also be there.

The strong points of the phenomenological approaches cover the advantages given by the comparative theology: it also starts from the demand of being rooted in own culture. But the strongest principle of such an approach is in the fact that it demands to keep balance between the requirement of self-restraing both in judgments and in sympathy involvement into religion under investigation, and the requirements of deep understanding the religious patterns, 
which lay in the base of a religious worldview. Nevertheless such an approach leaves the question about truth and values in its ambiguity. It is not clear what a phenomenologist of religion should do with his/her own understanding of truth and values. Should he correlate or make the choice or recommend something, based on the results of his/her phenomenological study? Or he should restrain himself from any judgments for ever.

Oberhammer's approach, elaborated in the frame of Religious Hermeneutics, involves new terms (encounter, mythization and so on), which provide the pure philosophical character for study of religious and philosophical systems of India, and real protection from the weak points of the other approaches, which are restricted with the concrete theologies.

\section{REFERENCES}

[1] Oberhammer, G. Introductory remarks to Studies in Hinduism IV. On Mutual Influences and Relationship of Vishishtadvaita and Pancaratra. Edited by Gerhard Oberhammer and Marion Rastelli. Wien 2007. P. 36.

[2] Clooney Francis X. Comparative Theology - As Theology / Interreligious Hermeneutics in Pluralistic Europe. Between Texts and People. Edited by D. Cheetham, U.Winkler, O. Leirvik, J. Gruber. Amsterdam, New York. 2011. Pp. 132-133.

[3] Op. cit., p. 133.

[4] Ibid.

[5] Op. cit., p. 137.

[6] Op.cit., pp.144-145.

[7] Albertina Nugteren. Entitled to Understand. A critical Look at Comparative Theology / Interreligious Hermeneutics in Pluralistic Europe. Between Texts and People. Edited by D. Cheetham, U.Winkler, O. Leirvik, J. Gruber. Amsterdam, New York. 2011. Pp. 149-160. P. 150

[8] Op.cit., P.152.

[9] Francis X.Clooney. theology after Vedanta. An Experiment in Comparative Theology. New York. 1993. P.190.

[10] Albertina Nugteren. Entitled to Understand. A critical Look at Comparative Theology / Interreligious Hermeneutics in Pluralistic Europe. Between Texts and People. Edited by D. Cheetham, U.Winkler, O. Leirvik, J. Gruber. Amsterdam, New York. 2011. P.153.

[11] Magdalen Lambkin. Towards an Interreligious Hermeneutic of Scripture. Problems and Possibilities / Interreligious Hermeneutics in Pluralistic Europe. Between Texts and People. Edited by D. Cheetham, U.Winkler, O. Leirvik, J. Gruber. Amsterdam, New York. 2011. P. 107.

[12] John Braisted Carman. The Theology of Ramanuja. An Essay in Interreligious Understanding. New Haven and London, Yale University Press, 1974. P. 4.

[13] Op.cit., p. 5.

[14] Op.cit., p. 7.

[15] Op.cit., p. 8.

[16] Halina Marlewich. The Religious Hermeneutics of Gerhard Oberhammer and the Investigation of the Philosophical Traditions of India // Proceedings of the 3rd International Conference on Contemporary Education, Social Sciences and Humanities (ICCESSH 2018). [internet resource]: https://www.atlantispress.com/proceedings/iccessh-18/25898211

[17] Ibid.

[18] Gerhard Oberhammer. Der Ort, an dem sich Gott ereignet // Die Relationalität des Subjektes in Kontext der Religioshermeneutik. Arbeitsdokumentation eines Symposiums. Herausgegeben von Gerhard Oberhammer und Marcus Schmucker. Wien, 2011.
[19] Francis X. Clooney. Theology after Vedanta. An Experiment in Comparative Theology. New York. 1993. P. XV. 